\title{
Path dependence and path plasticity: textile cities in the Netherlands
}

\begin{abstract}
Concentrating on three Dutch cities that once had an important textile industry, this study discusses the reasons for the decline of the industry and the responses by firms and other relevant actors. Reasons and responses differed between cities. Therefore, general explanations of the decline of the Dutch textile industry must be supplemented with city-specific accounts. We do not deny that the industry had to deal with path dependence, and lock-in was looming large, but we argue that the demise of the textile industry was not inevitable. The notion of path plasticity helps to direct attention to options that could have been chosen.
\end{abstract}

Keywords: path dependence, path plasticity, textile industry, urban economy, industrial decline

\section{Introduction}

This paper explores the concepts path dependence (and its corollary lock-in) and path plasticity in an investigation of the decline of the textile industry in three Dutch cities that had a leading position in this industry by the middle of the 20th century. For many years, these cities and their economies appeared to be following a beneficial path of economic and technological specialization, but at some point the trajectory turned into a disadvantageous one. We concentrate on the processes and circumstances that gave rise to an inability-to-change syndrome, and examine firms' and other actors' responses to perceived decline until the point at which they had run out of options. A few companies survived, which shows that lock-in is probably never complete. The concept of path plasticity has been coined to indicate that the path being followed is seldom a dead-end street and indeed is being shaped by the actors themselves as they go along.

The notion of path dependence was originally developed in economics, but came in use in various other fields, among them economic geography. In his influential study of the Ruhr Area, GRABHER (1993) argued that cities and regions can become locked-in after following a path of successful economic development. Companies as well as public authorities are increasingly unable to deal with changing circumstances and, as a consequence, economic decline sets in. While the possibility of a state of lock-in is widely ac- knowledged, little or no attention has been given to the circumstances leading to it. Lock-in is not caused by outside influences. Actors follow a trajectory that reduces their freedom of action. This becomes only apparent when outside circumstances (new competitors, new technologies) call for new, untried responses. Our paper contributes to the literature by focusing on this process by which actors locked themselves up and continue to do so in the face of an urgent need for change. When and why does this happen?

In the next section we discuss the relevant literature in more detail. Following a brief description of our methods of data collection and we review the development and decline of the textile industries in Enschede, Tilburg, and Helmond consecutively. Our focus is at the level of the individual actors, but includes the political and social environment affecting their decisions. Then we compare the three cases in order to identify and explain processes of choice narrowing. We then return to the broader theoretical question of local or regional path dependence and path plasticity. In a final section, we look at the present situation in the three cities and the development of their economies after the demise of the textile industry.

\section{Path dependence and path plasticity}

The constraining effects of history have always been known, but they became a major subject of 
study as a result of the work of economists Brian Arthur and Paul David, and especially their notion of path dependence. Arthur and David saw path dependence as a means to show that equilibrium models fail to explain the dynamics of the economy (ARROw 2000). They focused on technological development, studying cases as diverse as the diffusion of reapers in agriculture, keyboard layout, and video recording systems. What they found was that initial conditions, which may be the result of historical accidents, can have strong and lasting effects. These effects can be detrimental. Arthur and David stressed the possibility of suboptimal, inefficient outcomes, arguing that economic explanation must take historical events into account.

Perhaps the best-known example of path dependence is the QWERTY keyboard (DAVID 1985). It would become the canonical example of path dependence (MARTIN/SUNLEY 2006). It is an instructive example, demonstrating the working of positive feedbacks, but it has also given path dependence its connotation of wrong choice. In his discussion of QWERTY, DAVID $(1985,336)$ stated that "competition in the absence of perfect futures markets drove the industry prematurely into standardization on the wrong system - where decentralized decision making subsequently has sufficed to hold it." Here the claim is that markets may function in such a way that an inefficient technology gains dominance, and that this unfavorable state of affairs is persistent because decentralized decision making (the market) means that no actor is capable of repair. Equilibrium-based economics does not account for such a suboptimal outcome (ARTHUR 1990).

The assertion that the present state of an object of study - a technology or an urban economy - is influenced by its previous states requires that an object can be specified, and the systems concept is often used for the purpose. But it is not the object itself that is path dependent. The QWERTY keyboard is not reproducing itself but continues to be produced by manufacturers whose decision to do so is sensible as long as a market for such keyboards exists. The systems concept refers to the interrelated sets of actors involved in continued production, but no distinction is made between objects of study that are well-defined and objects of study that are hard to delineate. This difference can be phrased in terms of tightly versus loosely coupled systems, with degree of interdependence and degree of indeterminacy as defining characteristics (ORTON/WEICK 1990).
Perrow $(2009,219)$ shows the significance of this distinction, noting that "loosely coupled systems tolerate processing delays, changes in the order of sequences, and alternative methods; there is slack in resources, and buffers, redundancies, and substitutions are available. Tightly coupled systems are not tolerant in these ways." His emphasis on the order of sequences is noteworthy. Path dependence means that "future events are not independent from past events and the sequence of events makes a difference for the outcome" (GLÜCKLER 2007, 620).

The distinction between tightly and loosely coupled systems provides a theoretical basis for observing changes in the nature of systems over time. A loosely coupled urban economy may develop into a tightly coupled one, or the other way round. In addition, the distinction directs attention to the difference between endogenous and exogenous sources of change. Especially in a loosely coupled urban economy it can be difficult to tell the difference between endogenous and exogenous sources, which is important because the literature on path dependence emphasizes that path changes must be explained in terms of endogenous factors, i. e. factors internal to the system (Boschma/MarTin 2010).

As a rule, technological systems will be more tightly coupled than urban economies. They consist of components that interact with one another under a larger system architecture (GARUD/ KUMARASWAMY 1995). Typical of technological systems is the presence of a single reference object with a life cycle of restricted duration (ADNER/LeVINTHAL 2001). Urban and regional economies, in contrast, have many reference points (MARTIN 2010) and the life cycle metaphor is of limited use. They usually contain several industries, which is why "a model of regional development paths must allow for technologically unrelated regional actors" (BATHELT/ BogGS 2003, 269). Moreover they involve public and private institutes dedicated to learning, housing, governance, health, or leisure. Not all these industries and institutes fit into a single system architecture. Therefore the mechanisms that may explain path dependence in technological systems cannot be supposed to apply fully, without adjustment, to urban economies.

Path dependence is not necessarily disadvantageous. The concept refers to economic activities that are self-reinforcing. The phrase "positive lock-in" is sometimes used for self-reinforcing 
growth processes (MARTIN/SUNLEY 2006; SYDOW/LERCH/STABER 2010). In the absence of such processes, dominant designs would not be possible and de facto standards would not emerge. These examples relate to technological systems but geographical examples can be given as well, most notably spatial agglomeration. While often advantageous, self-reinforcing processes may also discourage the search for alternative lines of activity, as actors are more or less forced to devote all their efforts to sustain the current path. When a technology or product is successful, practitioners will stick to a specific set of options for further development, in line with the concept of technological paradigm (CONSTANT 1973). Comparable are GrabHER's (1993) notion of world view, a shared view that "determined which phenomena were perceived and which phenomena were ignored", and DosI's (1982) disembodied part of technology that consists of expertise, experience, and stateof-art knowledge.

In short, processes of path dependence favor economic growth while reducing variety. Under conditions of strong path dependence only a single path is available - but it is a good path, at least in the sense that so far it has been worth pursuing. A problem arises when there is reason not to continue on this path, for example when firms expect profits to erode, when competing technologies become available, or when government sets new rules. Those with interests in the old path - producers as well as consumers - will find it difficult to change their course as they invested time, money, and effort. Moreover, few options will be available to firms since alternative paths were not explored - where available means that they are perceived and deemed feasible by those in charge. The notion of lock-in describes such a state of affairs. Lock-in, then, denotes the absence of visible options when they are needed. A successful car making firm is not thought of as locked into car making. But when this firm is proficient in internal combustion engines and the car market shifts to electric cars, we may say that it has become locked-in. Now, markets do not change overnight and firms are not suddenly out of options, but in the end a firm suffering from lock-in that fails to find a way out will not survive. For a city or a region this is hardly a conceivable outcome. There are many cities that once were major economic centers, then fell into stagnation, but did not disappear. What is more, many examples can be given of cities that suffered from decline and then man- aged to recover, which raises the question what exactly is meant by urban or regional lock-in.

GRABHER (1993), in an early study of regional lock-in, distinguishes three different forms. Functional lock-in indicates the efforts of large firms to keep their environment predictable by maintaining stable interfirm relations. These efforts include exchange relations that require specific investments and thus lock firms into a system of mutual dependence. Cognitive lock-in denotes a shared and mutually reinforcing world view of the actors involved. Political lock-in refers to symbiotic relations between political and administrative actors and regional industry. When these actors join forces to preserve existing industrial structures, new initiatives are hampered. These three forms represent different mechanisms that may, alone or in combination, contribute to a state of urban or regional lock-in.

Grabher points out that the coal, iron, and steel industries in the Ruhr Area developed into a closed, tightly coupled system, and he argues that an open, loosely coupled regional system will help to overcome economic standstill. $\mathrm{He}$ does not, however, discuss whether an inabilityto-change syndrome requires that all the factors mentioned are present, nor does he trace back the paths that resulted in decline. Such an analysis could reveal the point at which a specific factor becomes disadvantageous (for example, a world view that becomes closed enough to prevent recognition of new business opportunities) and it might show the point where it becomes impossible for economic actors to leave the dominant path. These are important themes in relation to the geographical study of path dependence.

Path dependence is not a determinist concept, but emphasizes that choice can become limited (GLÜCKLER 2007). The concept of path plasticity focuses on the possibilities for innovation that are still present within a dominant path (STRAM$\mathrm{BACH} 2008$ ). Path plasticity is an important counterpart to path dependence as it stresses that the future is essentially open: There are always opportunities to move in a new direction. But how long are the actors involved in a path dependent trajectory able to perceive these possibilities, especially under conditions of acute pressure? This is the central question in our study of the microdynamics of industrial decline in the textiles sector in the Netherlands. We investigate whether firms' reduced ability to adapt to changing circumstances can be attributed to tight coupling in 
an urban economic system and whether Grabher's three forms of regional lock-in are necessary conditions for an inability-to-change syndrome or, in other words, necessary conditions for reduced path plasticity.

\section{Setting and method}

Enschede, Tilburg, and Helmond were main centers of textile industry in The Netherlands in the 20th century. A fourth, Almelo (close to Enschede), is not included in this study since its recent history as a textile city coincides with the history of a single company, Ten Cate (Noor et al. 2008). Each of the three cities saw its textile industry recover from World War II, but starting to decline around 1960. In a few decades, all textile firms disappeared from Enschede and Tilburg, and only two remained in Helmond. The scale of these cities is incomparable to the Ruhr Area, and the textile industry is very different from coal, iron, and steel (HASSINK 2007), but an inability-to-change syndrome is discernible that resembles what Grabher found.

In our study we consider actors operating at the firm level, but also actors operating at the city level. Written sources have to be relied upon because few actors involved in decision making in the 1960s and 1970s are still available for interviewing. Sources include scientific publications (journals, dissertations, monographs), policy documents, background studies, newspapers, industrial and regional magazines. ${ }^{1}$ The nature of sources differs between the three cities. For Enschede some firm histories are available, but many city level economic, social, and political sources have not yet been opened up. Sources concerning Tilburg emphasize social and political issues at the city level while firm histories are nearly absent. Sources concerning Helmond are scarcer, but some detailed policy documents are available.

The quality of decisions made will not be examined. Instead we relate past decisions to the urban or regional context in which they were made, and to business paradigms that prevailed at the time. The resulting account does not discredit the factors that are usually brought up to explain the demise of the Dutch textile industry, but we argue that these factors do not provide a sufficient explanation. Shortage of labor, high labor costs, and shrinking demand are often mentioned (VAN NEDERVEEN MEERKERK/HEER-
MA VAN Voss / Hiemstra-Kuperus 2010). While these factors may be valid, they do not account for differences between cities or between firms within a city. We propose some further, more specific factors, starting from a description of the era of textile crisis that in each city started around 1960 and continued until the 1980s. While the era of crisis was more or less similar in the three cities, the moment of acute crisis was not. The role of timing has to be stressed for several reasons. Firstly, cities that differ in the moment of crisis recognition will start to search for alternatives (including government support) at different points in time. In the Netherlands of the 1970s it made quite a difference whether such a search started before or after the first oil crisis. Secondly, the textile industry was diverse, ranging from firms specialized in the mass production of fabrics to firms producing small batches of high quality materials. These firms were dissimilar in terms of product life cycles and the time needed to recover investment costs. Thirdly, the circumstances that produce lockin may come very fast or more slowly, in line with the distinction between "immediate powerful impact versus those that manifest as chronic 'slow burn' trends" (SIMMIE/MARTIN 2009), affecting different branches of an industry in dissimilar ways.

\section{Paths of textile production in three cities}

Before 1800 , small scale production of textiles was taking place in many towns and settlements across the Netherlands. Larger scale production was restricted to a few cities in the coastal provinces, notably Leiden and Haarlem, where manufacturers from the Southern Netherlands had settled after 1585, when the city of Antwerp was taken by the Spanish army. Soon, merchants from these two cities would turn to smaller towns in other parts of country for cheaper processing of raw materials. Today we would speak of outsourcing. Thus, Tilburg produced woolen fabrics that were finished in Leiden while Helmond produced linen, later also cotton fabrics for Haarlem. In the 19th century, Tilburg would replace Leiden as the centre of the Dutch wool industry. Helmond and Haarlem had a more complicated relationship but both cities were heavily dependent on the export of colored fabrics to the West Indies. By the end of the 18th century this was a sinking trade, due to war and monetary crisis. The Haarlem textile industry would never regain its former position, and Helmond became a cen- 
tre of textile industry again only in the late 19th century.

Meanwhile, large political events were taking place. France occupied the Netherlands in 1795. After Napoleon's defeat, the Northern and Southern Netherlands were united at the Congress of Vienna as Kingdom of the Netherlands. The government of the newly created kingdom created a trading company (Dutch Trading Society, NHM in Dutch) to restore relationships with the Dutch East Indies that had been under British control during the French occupation. Compulsory imports of Dutch cotton by the East Indies became part of an integrated system to organize colonial production and trade (BosmA 2007). Initially this cotton was produced in Ghent, in the South. When the South seceded in 1830 , creating the state of Belgium, NHM looked for producers in the North. They were found in Twente, a region at the German border that had a long history of cottage weaving. Helmond, close to the Belgian border, was not seen as a candidate because of the risk of contraband fabrics. Backed by exports to the East Indies, Twente developed as an important industrial area, specialized in cotton, with Enschede as the largest city. Thus, the textile industries of Enschede, Tilburg and Helmond had been there for ages, and it was difficult to imagine in 1960 that they would practically be gone 30 years later.

\section{Enschede}

Firm alliances had always been rare in Enschede, and in the Twente region in general, but became more common in the 1950s. Trendsetting was a profit-sharing agreement of Ten Cate and $\mathrm{KSW}$ Nijverdal in 1952 that was later followed by complete merger. Textile firms were familyowned, and industrialists in the region cherished their firm's autonomy as a way to protect the family interest. This familism meant that family and firm were interdependent. In the late 1950s family ties weakened and the number of mergers increased. Widely acknowledged is the influence of Wisselink, son of a textile manufacturer and professor in Rotterdam, who advocated a combination of horizontal concentration and vertical integration.

A list of only the most prominent events includes the merger of Blijdenstein and Willink (Winterswijk) in 1959; the closure of Jannink in 1962; the creation of Royal Textile Union (KNTU) in 1962, a merger of no less than ten sizable firms that ended in bankruptcy in 1972; the Van Heek \& Co merger in 1964, followed by the decision to discontinue production in 1967; the merger of textile printing firm De Nijverheid with Van Vlissingen (Helmond) and Ankersmit (Deventer), forming Texoprint, still present in Helmond under the name Vlisco; the formation of government-led Spinnerij Nederland in 1978, an attempt to rescue parts of Dutch cotton-spinning that lost momentum when Schuttersveld went bankrupt in 1982 and that was discontinued when Bamshoeve closed in 1990. All these mergers, acquisitions, and closings have been documented by Hesselink (2010). The list shows that the decline of the industry in Enschede took thirty years to unfold. Between 1960 and 1980 the number of textile firms in Enschede fell from 48 to 15 , the number of clothing firms from 40 to 12 , and 18000 jobs were lost. In $1950,64 \%$ of the city's employment had been in these two industries, a percentage that fell to $44 \%$ in 1960 , $20 \%$ in $1970,7 \%$ in $1980,3.7 \%$ in 1990 .

Shortage of labor, seen as a major element in the demise of the Dutch textile industry, was particularly pressing in Enschede. The shortage had many causes. VAN NederveEn MeERKERK / HEERMA VAN VOSS / HIEMSTRA-KuPERUS (2010) point at the industry's poor reputation. Wages were low, working conditions were bad (heavy, monotonous work under a tight schedule in factories that were dusty and deafening), and management was paternalistic. VAN HoOfF / Rossel (2002) add limited promotion opportunities, resentment that resulted from a lost strike in 1931-1932, the old system of fines, and the fact that textile firms were no longer seen as reliable employers after massive lay-offs in the 1930s. Workers also disliked the shift system that was introduced in the early 1950s. Prospects had always been poor to find other work in a city so heavily dominated by its textile industry. Now, in the postwar period, jobs in other sectors became available and especially young workers evaded textiles.

We will not engage in a discussion of all the factors that shaped the course of the cotton industry in Enschede, such as the dominant position of Van Heek or the absence of institutions to temper class conflict. Instead we focus on responses to labor shortage in the region. A general reaction was that firms increased wages (not seldom paying under the counter), and that they sped up the pace of automation, leading to higher labor productivity but also to less flexibility and 
greater debts. Attempts were made to restore the reputation of the industry by better education and employee participation, and by methods ranging from improved relations with schools to a shared company journal and advertising (VAN Hooff / Rossel 2002). An understandable but in retrospect striking response to labor shortage was that no measures were taken to broaden the region's economic base. As late as 1961, the director of the provincial institute for industrial development was quoted saying that "Over the past years we have not even thought of trying to attract industry to Twente. The labor market is too tight. At this moment, Twente is not an attractive place for new establishments" (BUTER, 1961, 54f.).

Labor shortages sooner or later led to rising wages, which are often blamed for the loss of competitiveness of the Dutch textile industry. Around 1960 wages in the Netherlands began to rise after a lengthy period of low wages that started in the 1930s and continued in the 1950s. General statistics for the 1960s show that production costs per unit in the Netherlands were comparable to those in other West European countries. However, this may not apply to textiles. VAN GorP (1987, 205) and HESSELINK (2010, 176), insiders in the industry, stress that wages in the Dutch textile industry increased more than in neighboring countries. The issue of wages and production costs is still being disputed, but what counts here is the observation that Dutch textile firms lost much of their home market to competitors from other European countries. Small price differences may have played a role in an international market that struggled with overcapacity and low margins. In addition to that, the Dutch government was less willing than governments in neighboring countries to protect its industry. Some support was given in the form of loans for the purpose of modernizing machinery, but trade restrictions were refused. This was in line with a long-standing free trade orientation in Dutch economic policy but it also reflected the view, prominent at the time, that industrial support should not go at the expense of developing countries. Many believed that the Dutch textile industry was competing with low wage countries, but the fact is that in the 1970 s the textile industry was still dominated by industrialized countries.

Next to labor shortages and rising wages, shrinking demand is often seen as an explanation for the demise of Dutch textile. Four developments must be mentioned. Firstly, the Dutch clothing industry, a main buyer of textile products, collapsed in the 1970s (SCHEFFER/DuINEVELD 2004). Secondly, consumer preferences changed, which affected the wool industry in particular (VAN GORP 1987) but also had its impact on the cotton industry. Thirdly, when non-textiles appeared as substitutes for cotton handkerchiefs and napkins the opportunity was not seized by any of the textile firms in Twente - who saw themselves as textile manufacturers, not as providers of a product function. Fourthly, relations between the Netherlands and Indonesia, already strained after Indonesia declared its independence in 1945, worsened in 1957 as a result of the dispute over West New Guinea. Dutch companies left Indonesia and cotton exports came to a halt. Enschede firms that produced for the Indonesian market had to shift to markets in Europe and Africa. For a few years they profited from growing international trade and the start of the European Community, but poor performance in the early 1960 s made them resort to mergers that would soon prove to be useless.

The history of the Enschede textile industry is to a large extent the history of individual firms, and so is the history of its demise. There is no sign of an important role played by local or regional government, and central government stepped in when most damage had already been done. Industrialists in Enschede had always kept government at arm's length as they wanted to fight their own battles. It took a while before it began to dawn on them that the decline of textile industry was structural, not another period of recession that would be followed by recovery (BENNEWORTH/Hospers 2007). When finally a policy plan was made for the sector it became clear that solutions were hard to find, especially because the Dutch government declined both protectionist measures and financial support for individual firms.

\section{Tilburg}

Compared to Enschede, Tilburg had a more diverse economy that included not only the textile industry but also shoe and cigar manufacturing and firms in the broad metals category. The textile industry, specialized in wool, was the largest in terms of employment. Its shape was different from the Enschede cotton industry. Textile firms in Tilburg were smaller in size, on average, their number was larger, and no single firm was dominating the scene. SCHEFFER (2009) ascribes this smaller size to a self-enforcing cycle of 
production for a small market (the Netherlands and Belgium) that prevented specialization and economies of scale. Firm dynamics were also different. Many firms in Enschede had been founded by persons who had become rich in the textile trade. Many of the Tilburg companies had been started by enterprising workers, teaming up with someone who provided capital. While most firms in Enschede were owned for generations by a single family, many Tilburg firms had been established as a partnership, a legal form that allowed more easily for ownership changes. Thus mergers, collaborations, start-ups, and failures were not uncommon in Tilburg. However, in the second half of the 1950s the number of mergers and failures increased dramatically. VAN Doremalen (2001) presents a list of 44 textile firms that closed down in the period 1957-1979, and VAN GORP (1987) needs a very lengthy chapter to describe the events that marked the decline of the Tilburg wool industry.

Between 1960 and 1970 employment in the textile and clothing industries went down more in Enschede (55\%) than in Tilburg (39\%). Surprising is that Tilburg responded earlier to perceived crisis than Enschede. Already in 1966, a study was commissioned to investigate the structure of the Dutch wool industry, much of which was concentrated in Tilburg. In this period, the wool industry also asked the Dutch government for protection against imports. Such crisis awareness cannot be found in Enschede in this period. It must be noted that industrialists in Tilburg had always been more in favor of government intervention than those in Enschede, but Tilburg also had a clear explanation for the stagnation while Enschede did not. The explanation was unfair competition from Prato. Prato had greatly enlarged its market share in Europe since the start of the European Community. Tilburg industrialists were convinced that Prato firms received illegal government support.

VAN GoRP (1987) and ScheFfer (2009) point out that price competition from Prato was only one factor that made the Tilburg wool industry decline. Another was decreasing demand for wool products. After the postwar reconstruction years of the 1950s the Dutch population became wealthier and more fashion-conscious, and dressing habits changed. Cotton jeans became popular. Central heating systems reduced the need for warm clothing. Duvets replaced woolen blankets. Synthetic fabrics entered the market. Demand for manual knitting wool faded away.
To make things worse, the Dutch army decided to buy its uniforms elsewhere. But sales would have dropped even if the market for wool had been stable, as the Tilburg wool industry was not very competitive. Labor was in short supply, for the same reasons as in Enschede. Labor costs were high and in the wool industry they were not compensated by high labor productivity. Many firms continued to work with old technologies unsuitable to meet fast-changing demands. To explain the low level of investment, VAN GORP (1987) notes that firms did not have the means to invest, and it was difficult to attract outside capital. He also suggests that industrialists hesitated to make timely investments as this would have meant lay-offs. KEUNE (1991), however, states that employers gave priority to their own interests, at the expense of the firm and its employees. Many created family-owned holdings and turned the original firm into a production unit that rented buildings and machinery from the holding. As a result, bankruptcy of the firm would hardly affect family possessions.

Changing demand, rising labor costs, small-scale production, and outdated technology were structural weaknesses that became manifest after the start of the European Community. Between 1957 and 1962, Dutch wool imports (fabrics and yarn) increased by $76 \%$. Between 1965 and 1976, the consumption of woolen fabrics decreased by $65 \%$. In 1956 the Dutch industry had $80 \%$ of the home market, in $197611 \%$. Developments were less dramatic in worsted production but here too the loss of market share was considerable, from $72 \%$ in 1960 to $40 \%$ in 1976 . Thus the Tilburg wool industry was unable to compete on the European market. Prato was blamed, but allegations of illegal subsidies could not be substantiated. Instead, VAN GORP (1987) observes that Prato's fabrics were second-rate (yarn was spun from old clothes, strengthened with synthetic fibers) and that most of the work was done by home workers.

\section{Helmond}

With 58000 inhabitants in 1972, Helmond was smaller than Enschede or Tilburg. It was an industrial city, dominated by textile and metal industries, of which textile was the largest in terms of employment. Most of the textile production was cotton, but Helmond firms also produced woolen fabrics. Cotton manufactured in Helmond was different from Enschede, with its history of plain weaves made in large volumes for 
the East Indies. Smaller Enschede firms were less export-oriented, but also produced plain weaves in a variety of qualities. In contrast, Helmond was specialized in colored fabrics, a heritage of the old production in commission of Haarlem traders. Related to colored fabrics, Helmond had dyeing and printing firms. As the weaving of colored fabrics and the dyeing of cloth were difficult to mechanize, firms in Helmond had long relied on home workers. Mechanization began to spread in the last quarter of the 19th century, but only after 1900 would Helmond textile firms start to grow, reaching their peak in the $1950 \mathrm{~s}$ when the largest three firms alone employed 7000 people, most but not all in Helmond.

After 1960, firms in Helmond would get their share of the textile crisis. In 1960-1967 male employment in the Helmond textile industry decreased by $30 \%$, which was not so different from developments in Enschede and Tilburg but it seems that Helmond felt the effects earlier. In 1968 the City Council installed a committee to look into the city's economic, financial, social, and cultural state, which soon published a report that sketched a gloomy picture. The report made every attempt to show that the city was in a dreadful position. It noted that 2500 jobs in the textile industry were lost since 1960, that the metal industry did not perform well, and that the problems were likely to persist. It also noted that over $60 \%$ of male workers were employed in manufacturing, $70 \%$ of whom in textiles and metals, sectors in danger of decline. The conclusion was that the structure of employment was one-sided. A comparison was made between the rate of male unemployment in Helmond (5.4\%) and other cities in the province, and it turned out to be even higher than in Tilburg $(4.3 \%)$. The Helmond workforce was poorly qualified. Lowskilled work was overrepresented, and average wages were relatively low. The number of new jobs was smaller than elsewhere. The city was unappealing, suffering from delays of maintenance, and its financial state was very weak.

While emphasizing that Helmond and its surrounding municipalities were closely linked, the report ignored that economic development in these municipalities was more positive. Industrial employment in Helmond decreased by $25 \%$ in 1960-1967, but in the surrounding municipalities it increased by $37 \%$. Still the report seems to have worked well. In 1971 the Minister of Economic Affairs installed a new committee to investigate the problems of Helmond, which arrived at similar conclusions. In the next years the Dutch government would give Helmond preferential treatment. Extra funding alleviated the city's financial problems, the status of growth city was given as part of a new spatial planning policy to reduce congestion problems in urbanized areas (Helmond is near Eindhoven), and it became eligible for investment subsidies, an instrument to stimulate economically weak regions. In 1975 Volvo Car received a subsidy for building its new headquarters and a development and test centre in Helmond, noteworthy because the company had no connections with Helmond.

Such measures were certainly needed to improve social and economic circumstances, but they were based on an analysis that depicted the Helmond industry as one-sided. In reality, compared to Tilburg and Enschede the Helmond industry was fairly mixed. Next to textiles and metals there was a range of other industrial activities that included food, machinery, packaging, and furniture. Moreover, the textile industry in Helmond would not disappear. Textile firms were in trouble since the late 1950s and some had terminated production. But Texoprint, the firm created by the 1964 merger of Van Vlissingen, Ankersmit, and De Nijverheid, had a strong position on the West African market (CLARK 2010). In 1969 Texoprint merged with Hatéma to form Gamma Holding, as a result of which interior decoration fabrics were added to the firm's product range (HESSELINK 2010). The other surviving firm is Raymakers, a smaller firm after it closed down most of its spinning and weaving facilities to focus on the production of velvet.

\section{Industrial decline and path plasticity}

In each of the three cities the textile industry went through a crisis that resulted in the liquidation of nearly all firms, in more or less the same period. Policies to rescue parts of the industry were of little avail. Firms disappeared almost regardless of their branch of industry (cotton, wool, worsted), geographical market (home market or export), production activity (spinning, weaving, finishing), or technology (leading or lagging). Explanations of the decline of the Dutch textile industry tend to emphasize general factors such as labor shortages, high wages, declining demand, foreign competition. Explanations along the lines of path dependence, however, emphasize factors internal to the industry leading to a more or less collective inability to 
react to environmental disturbances. The emphasis on general explanatory factors reflects the widespread conviction that the demise of Dutch textiles was inevitable. But was it? Was the industry moving along a dead-end trajectory? Or were all the failing companies simply unable to see the way out?

When the textile crisis began, around 1960, some firms closed down almost immediately while other firms continued to exist for many years. When exports to Indonesia slowed down, exporting firms Van Heek \& Co and Rigtersbleek (Enschede) found themselves in the same situation as Ten Cate (Almelo) but they closed down while Ten Cate survived. Economic conditions were worsening but apparently there was still room for choice - which implies path plasticity. One firm made decisions that worked well while another made decisions that brought collapse nearby.

Firms' decisions can be related to city- and firmlevel differences. Moreover, the reasons for firms' failure in later stages of the textile crisis may have been very different from earlier failures. We will first discuss firms' and other actors' responses to perceived decline. Then we return to the broader theoretical question of local or regional path dependence and path plasticity. In particular we will discuss whether firms' reduced ability to adapt to changing circumstances can be attributed to tight coupling in an urban economic system.

A first observation is that the Dutch textile industry was an unlikely candidate for an inability-to-change syndrome. Dutch firms were accustomed to changing conditions. They had always dealt with economic cycles, economic depression, and political uncertainty. They had always adjusted to changing markets because most of the time they lacked home market protection. When in the 1950s the economic tide changed once more, many saw this as a next episode in a familiar process. Economists recommended upscaling of production and increased productivity through 'rationalization' as a response to foreign competition. Most industrialists subscribed to this view. In the period 1957-1965 many mergers were concluded, by firms from all three cities. A substantial number was with partners from smaller towns, where shortage of labor was less of a problem. Firms were also sold in this period. The reasons differed but included skepticism about the economic prospects of the industry, inability to finance investments, and problems of succession. But mergers were more frequent than takeovers. Speaking of this period, HESSELINK $(2010,144)$ observed "a positive attitude and optimism about the future" in Twente, and many textile firms did renew parts of their machinery (VERSTEGEN 1993).

Concerning the strategic direction of renewal, the industry was torn between two ideas: largescale, low-cost production, or diversified production in small batches. The latter, often chosen, implied a focus on the European market with its emphasis on fashionable, fast-changing fabrics. Few Dutch textile firms, however, possessed the marketing skills needed for such a market. In most firms technical and financial issues had been the main focus and industrialists were unable to make a swift change to a new orientation. This applies especially to firms in Enschede, where the upstream activities of spinning and weaving were more important than finishing, dyeing, and printing. But it also applies to Helmond, where the largest firm, producing waxprints for the African market, relied heavily on its sales agency, a trading house, for market information (CLARK 2010).

Responses in Tilburg are harder to recount. Here the number of firms was larger and the range of responses wider than in Enschede or Helmond. Low-cost production was hardly an option. Most firms in Tilburg were too small for that. Moreover, capital goods were largely outdated and many firms were unable to finance new machinery. Instead they would close, merge, shed part of their production (often spinning), or relocate production to a country with lower wages. In the early years of the crisis a closing firm or a redundant activity was taken over by another firm. Later on, takeovers became infrequent.

There are signs that industrialists in Tilburg had an early awareness of the crisis. KeUne (1991) insists that many firm owners viewed liquidation as a more profitable option than business continuation. The effects of early business closures were significant. Initially production was taken over by other firms and textile workers kept their jobs, but the atmosphere changed as firms began to take the prospect of decline for a fact. A knock-on effect is likely. When a weaving firm terminated production, a spinning firm lost a customer. When this spinning firm, in turn, had to terminate production, other weaving firms could run into trouble. Evidence is scarce but 
there is reason to think that a vicious cycle was at work in the Tilburg wool industry. General business conditions were unfavorable - intense competition, an unprotected market, falling demand, high costs of labor, financing difficulties - but it can be conjectured that the process of decline was set off by early departers, those who had early on lost confidence in the future of the wool industry. Their leaving started a negative cycle that deprived Tilburg of its agglomeration advantages.

In Enschede a comparable cycle was at work. Few examples can be given of industrialists in Enschede who gave up early, but large and unsuccessful combinations such as KNTU and the Van Heek \& Co merger were just as detrimental. Firms were severely weakened, a trade began in firm parts, which nearly always had disappointing results, and supply relations between spinning and weaving firms were disturbed. These relations were mostly at the local or regional level. Again evidence is scarce, but Ten Cate's buying up single spinners seems to have been one of the reasons to form KNTU, and Spinnerij Nederland was heavily affected by the failure of Schuttersveld. Thus a knock-on effect could be found in Enschede as well.

Both Tilburg and Enschede produced mainly for the clothing industry. When alternatives had to be found for declining exports to Indonesia, Van Heek \& Co diversified into tent canvas, which was a successful business but it started too late and it was too small to save the firm. In Enschede this was about as far as diversification would go. It is hardly a coincidence that the two textile firms that diversified much further did so after leaving Enschede in the aftermath of a merger. Blijdenstein-Willink (Winterswijk) started the production of Verosol, metal backed fabrics for curtains and blinds, and Nico ter Kuile (Neede) developed Nicolon, woven textile with a plastic coating for earth reinforcement and other geotextile applications.

In Helmond the industrial atmosphere was less restrictive. Cotton was the main raw material but wool and synthetic fibers were used as well. All stages of textile production were present, including printing and dyeing, but sooner than in Enschede or Tilburg would firms in Helmond switch to non-garment textiles such as furnishings and floor coverings. There was also more exchange between Helmond and the surrounding villages. Over the years, firms moved back and forth between Helmond and these villages. In Enschede and Tilburg such exchanges were less common.

Helmond had a moderately sized but significant metal industry that prevented a self-reinforcing process towards industrial monoculture. In Tilburg and Enschede, an increasingly dominant textile industry had absorbed and trained the available workers, which made these cities less attractive for entrants from other branches of industry. But the presence of a metal industry is not the only reason for greater plasticity in Helmond. As an older town, Helmond was less than Enschede or Tilburg a product of textile industry expansion, and boundaries between industrial elite and working class would always remain more blurred than in the other two cities. Especially in Enschede it was hardly conceivable that workers would start their own business.

To summarize, the Dutch textile industry faced poor economic prospects in the late $1950 \mathrm{~s}$, but responses varied in ways that reflected urban idiosyncrasies. Stronger knock-on effects occurred in Enschede and Tilburg than in Helmond. One firm in Helmond could rely on a niche market (wax prints), but this and other firms also diversified into new textile branches earlier and more rigorously than firms in Enschede or Tilburg. Lock-in effects in these two cities were strong, and they were mainly cognitive. Especially firms in Enschede saw the city's cotton industry as a lasting phenomenon and falling demand as an interruption of an otherwise steady development path. This view was strengthened by the fact that the competences at their disposal - their own knowledge and skills but also those of their suppliers of materials and machinery, their sales agencies, the regional education system - were tailored to the production of fabrics for the clothing industry. Cognitive lock-in in Tilburg was similar but the spirit was different. Tilburg was the city of wool, its products of high quality, but wool was expensive, and when customers began to buy cheaper substitutes many in the Tilburg wool industry were inclined to think that they were fighting a losing battle.

Grabher's other forms of lock-in are difficult to discern. Functional lock-in - stable interfirm relations through specific exchanges that require specific investments - was nearly absent. In Enschede, collaboration was limited to a local employers' association. Collaboration among Tilburg firms was more developed. An employers' 
association served several common interests, there was a cooperative dyeing firm, and some base materials were jointly purchased. But these are not the forms of collaboration that lock firms into a specific system of production.

Political lock-in was also largely absent. Grabher speaks of symbiotic relations between political and administrative actors and regional industry. Compared to the Ruhr Area, relations between the Dutch textile industry and political and administrative actors were less regular. No preventive measures were taken to sustain the interests of industry. On the contrary, trade was given priority. It must be acknowledged that large amounts of public money were spent after the textile crisis had arrived, but it was mostly palliative support, not meant to be structural aid.

Grabher's forms of regional lock-in therefore offer only a partial explanation of the demise of the textile industry in the cities discussed in this paper. Cognitive lock-in was important, but it came in many shapes. It took industrialists, especially in Enschede, a long time to realize that problems were structural. Once they did, they first viewed upscaling of production as a solution. It was hard for them to think of new activities, away from cotton production for the clothing industry, or even hard to adapt to customer-led markets. But cognitive lock-in only became a factor after a mixture of early withdrawals and inadequate responses had set a downward process in motion that made the textile industry - wool and cotton alike - lose confidence. Organizational panic did the rest, together with high interest rates and falling prices.

\section{Epilogue}

Ever since the demise of the textile industry Tilburg and Enschede have been referred to as exemplars of impoverished industrial cities, but over time they managed to broaden their economic base - centered around education, healthcare, business services, and wholesale/ retail - and today little is left that reminds of a textile history. Indeed, in both cities the significance of manufacturing has become modest. VAN BOOM/MOMMAAs (2009) even state that Enschede and Tilburg went from crisis to comeback by making the transition from an industrial to a post-industrial economy. They note, in a cautious phrase, that both cities have overcome the initial problems brought about by the loss of the textile industry. However, VAN DER WAAL (2010) shows that both cities have not reached an advanced stage of post-industrialism. They are still lagging behind cities with a strong orientation towards business services.

In 2011, unemployment rates in Enschede $(7.9 \%)$ and Helmond $(8.5 \%)$ were well above the Dutch average of $6 \%$. In Tilburg it was $6.1 \%$. In Enschede and Tilburg employment in manufacturing was about $10 \%$. Helmond has retained more manufacturing industry $(20 \%)$ and the share of education and business services is lower, which reflects the fact that Helmond is not a regional centre. Textile is still present in Helmond, but with $10 \%$ of manufacturing employment (together with clothing) it is no longer a main sector. Today the most important sectors of industry are food and metal/plastics, both with $20 \%$ of manufacturing employment, and machinery, with $15 \%$.

The automotive sector is a small source of employment in Helmond, which is noteworthy in view of the automotive campus that is being created (PRUD'HOMME/DANKBAAR 2011). The campus builds on a development that started when Volvo founded a development and test centre in the 1970 s, encouraged by government subsidy. In 2005, ownership changes had left only a tiny part of the centre, and the city of Helmond started a resuscitation attempt - using an approach that was highly client-oriented. The attempt has been successful as various prominent firms and knowledge institutes have joined the campus. It will remain a high tech development and training center, not a manufacturing site. Comparable as a temporally remote event is business creation in Enschede related to Twente University. The university was founded in 1961 as a polytechnical college. In the 1970 s a policy was formulated to turn it into an entrepreneurial university with strong links to the regional economy and knowledge transfer and business generation as important objectives (BENNEWORTH/Hospers 2007). Since then, many spin-off firms have been created (BLAAUW et al. 2007) but their contribution to the regional economy is modest. The reason seems to be that many of these spin-offs provide business services in a region with few firms large enough to absorb these services. These examples show that after the failure of the textile industry it took Enschede and Helmond quite some time to find a new impetus for economic development. In Tilburg, in contrast, the city council created 
in 1958 already an agency to promote industrial foundings, followed by a plan to redesign the city and turn it into a regional centre of education, services, and industry.

Main employers in Enschede and Tilburg are in non-commercial sectors. Large industrial firms are scarce: Fujifilm and Bosch Transmission (formerly Van Doorne) in Tilburg, Vredestein (tires) and Grolsch (beer) in Enschede. Van Doorne started his firm in 1972; Fuji came to Tilburg in 1980, attracted by investment subsidies but also by the efforts of a former director of textile firm Janssens-De Horion. In Enschede, Vredestein and Grolsch were present long before the start of the textile crisis. Philips (1961), Polaroid (1965) and Ericsson (1990) set up subsidiaries in Enschede during and after the crisis, but left when products became obsolete or when the parent company centralized its operations. Helmond saw few examples of large investment by an external firm, apart from Volvo. Its economic growth has been largely autonomous.

Volvo in Helmond, the entrepreneurial university in Enschede, and the efforts of a Tilburg textile director are examples of threads that connect the present to the past. However, looking for such threads following the notions of path dependence and plasticity is not without risk. It is always possible to find something in the past - knowledge, skills, capital, institutions, technology, trade contacts - that with the benefit of hindsight can be seen as a precursor of present activities. In a strict sense it would be necessary to select phenomena from the past (without reference to the present) that at the time were seen as a seedbed for future growth. This stringent criterion is rarely met (for example, the Volvo site in Helmond was never meant as a first step towards an automotive campus). Precisely because examples that allow for causal, deterministic reasoning are rare, attempts to identify cases that link the past to the present are useful. They show the role of agency in processes that are ostensibly path dependent (GARUD/KUMARASWAMY/KARNøE 2010) and thus reveal path plasticity. Such attempts demonstrate the significance of industrial variety in an urban or regional economy - not as a way to diversify risks or to enhance cross-fertilization (though both are likely as well), but because variety increases the chance that some actors find a way out in a situation that most others consider a dead-end street.

\section{Note}

1 With few exceptions these sources are in Dutch. Partly for reasons of space we have omitted most Dutch language references. A version of the text that includes all these references is available from the authors.

\section{References}

Adner, R. / Levinthal, D. (2001): Demand heterogeneity and technology evolution: implications for product and process innovation. In: Management Science, (47)5, 611-628.

ArRow, K. J. (2000): Increasing returns: historiographic issues and path dependence. In: European Journal of the History of Economic Thought, (7)2, 171-180.

Arthur, W.B. (1990): Positive feedbacks in the economy. In: Scientific American, 262 (February), 92-99.

BAthelt, H. / Boggs, J.S. (2003): Toward a reconceptualization of regional development paths: is Leipzig's media cluster a continuation of or a rupture with the past? In: Economic Geography, (79)3, 265-293.

Benneworth, P. / Hospers, G. J. (2007): The new economic geography of old industrial regions: universities as globallocal pipelines. In: Environment and Planning C, (25)6, 779-802.

BlaAuw, G. / Groen, A. / Hospers, G.J. / Kirwan, P. / Van DER SIJDE, P. (2007): Economic development and entrepreneurship promotion in the region of Twente. In: Braun, G./ Diensberg, C. (Eds.): Cultivating entrepreneurial regions. Rostock.

Boschma, R. / Martin, R. (2010): The aims and scope of evolutionary economic geography. In: Boschma, R. / Martin, R. (Eds.): The handbook of evolutionary economic geography. Cheltenham, 3-39.

Bosma, U. (2007): The Cultivation System (1830-1870) and its private entrepreneurs on colonial Java. In: Journal of Southeast Asian Studies, (38)2, 275-291.

Buter, A. (1961): De motor die Twente deed groeien. In: De Mars, (9)2-3-4, 54-56.

Clark, G. (2010): Lincoln green and real Dutch java prints - Cloth selvedges as brands in international trade. In: Bevan, A. / Wengrow, D. (Eds.): Cultures of commodity branding. Walnut Creek, 197-212.

Constant, E. W. (1973): A model for technological change applied to the turbojet revolution. In: Technology and Culture, (14)4, 553-572.

DAVID, P.A. (1985): Clio and the economics of QWERTY. In: American Economic Review Proceedings, (75)2, 332-337.

Dosi, G. (1982): Technological paradigms and technological trajectories: a suggested interpretation of the determinants and directions of technical change. In: Research Policy, (11)3, 147-162.

GARUD, R./Kumaraswamy, A. (1995): Technological and organizational designs for realizing economies of substitution. In: Strategic Management Journal, (16)SI, 93-109.

Garud, R. / Kumaraswamy, A./ Karnøe, P. (2010): Path dependence or path creation? In: Journal of Management Studies, (47)4, 760-774. 
GLÜCKLER, J. (2007): Economic geography and the evolution of networks. In: Journal of Economic Geography, (7)5, $619-634$

GRABHER, G. (1993): The weakness of strong ties. The lockin of regional development in the Ruhr area. In: Grabher, G. (Ed.): The embedded firm, on the socioeconomics of industrial networks. London, 255-277.

HAssink, R. (2007): The strength of weak lock-ins, the renewal of the Westmünsterland textile industry. In: Environment and Planning A, (39)5, 1147-1165.

HesselinK, H.J. (2010): Strategische besluitvorming in een neergaande bedrijfstak. Onderzoek naar de strategische maatregelen in de KRL textiel-industrie in de periode 1950-2000. Enschede.

KeunE, L. (1991): De textiel voorbij. Tilburg.

MARTIN, R. (2010): Rethinking regional path dependence: Beyond lock-in to evolution. In: Economic Geography, (86)1, 1-27.

Martin, R. / Sunley, P. (2006): Path dependence and regional economic evolution. In: Journal of Economic Geography, (6)4, 395-437.

Noor, F. / Peters, S. / Stingelin-Stutzmann, N. / Smith, P. (2008): Going against the grain, the dematurity of the European textile industry. Fifth International $\mathrm{PhD}$ School on Innovation and Economic Development. Tampere.

Orton, J.D. / Weick, K.E. (1990): Loosely coupled systems: A reconceptualization. In: Academy of Management Review, (15)2, 203-223.

Perrow, C. (2009): Modeling firms in the global economy. In: Theory \& Society, (38)3, 217-243.

Prud'homme van Reine, P. / DankbaAR, B. (2011): The dynamic interaction between corporate and regional cultures: the case of Southeast Netherlands. In: Tijdschrift voor Economische en Sociale Geografie, (102)5, 532-547.

SCHEFFER, M. (2009): Fatal clusters. The evolutionary pathway of the Tilburg wool industry. In: Van Boom, N. / Mommaas, H. (Eds.): Comeback cities. Transformation strategies for former industrial cities. Rotterdam, 202-217.
SCHEFFER, M. / Duineveld, M. (2004): Final demise or regeneration? The Dutch case. In: Journal of Fashion Marketing and Management, (8)3, 340-349.

Simmie, J. / Martin, R. (2010): The economic resilience of regions, towards an evolutionary approach. In: Cambridge Journal of Regions, Economy and Society, (3)1, 27-43.

Strambach, S. (2008): Path dependency and path plasticity, the coevolution of institutions and innovation - the German customized business software industry. Marburg. (Working Papers on Innovation and Space 02.08).

Sydow, J. / Lerch, F. / Staber, U. (2010): Planning for path dependence? The case of a network in the Berlin-Brandenburg optics cluster. In: Economic Geography, (86)2, 173-195.

VAN BoOm, N./MOMmaAs, H. (2009): Urban regimes and evolutionary paths. In: Van Boom, N. / Mommaas, H. (Eds.): Comeback cities. Transformation strategies for former industrial cities. Rotterdam, 74-97.

VAN DER WAAL, J. (2010): Stedelijke economieën in een tijd van mondialisering: Arbeidsmarktkansen en etnocentrisme van laaggeschoolden in Nederlandse steden. Amsterdam.

VAN DoREMalen, H. (2001): Van industrie naar dienstverlening, arbeid en economie 1945-2000. In: Gorisse, C. (red.): Tilburg, stad met een levend verleden. Tilburg, 429-448.

VAN GorP, P.J.M. (1987): Tilburg, eens de wolstad van Nederland. Bloei en ondergang van de Tilburgse wolstoffenindustrie. Eindhoven.

Van Hooff, G. / Rossel, S. (2002): Human en public relations in de Twents-Gelderse textielindustrie, de Stichting Textielvak tussen beeld en werkelijkheid, 1950-1968. In: Textielhistorische Bijdragen, 42, 59-88.

Van Nederveen Meerkerk, E./Heerma van Voss, L./ Hiemstra-Kuperus, E. (2010): The Netherlands. In: Heerma van Voss, L. / Hiemstra-Kuperus, E. / Van Nederveen Meerkerk, E. (Eds.): Ashgate companion to the history of textile workers, 1650-2000. Farnham, 363-395.

Verstegen, S.W. (1993): De Sulzer weefmachine in Twente: een mislukte innovatie uit de jaren vijftig en zestig. In: Textielhistorische Bijdragen, 33, 163-183. 